\title{
A Question Answering Model Based Evaluation for OVL (Ontology for Vietnamese Language)
}

\author{
Dang Tuan Nguyen and Tri Phi-Minh Nguyen
}

\begin{abstract}
In this paper, we focus on using a Vietnamese Question Answering system to evaluate the OVL (Ontology for Vietnamese Language). The OVL has been evaluated using its effects as real component in question answering systems. This evaluation method helps us estimate the competence of OVL through following answered questions: which reasoning mechanism can be built up on OVL's structure and knowledge domain, which types of question can be answered from the reasoning mechanism, how to evaluate the experimental results.
\end{abstract}

Index Terms-Ontology, Ontology Evaluation, Question Answering.

\section{INTRODUCTION}

In the aim of contributing to Vietnamese language processing, we are now developing OVL (Ontology for Vietnamese Language) in a research project of the Natural Language and Knowledge Engineering Group at the University of Information Technology (VNU-HCM). The OVL's structure and its related details have been mentioned in [7]. OVL is now published as the first and open ontology [13] with the domain in various fields such as news, society, economy, culture, sport and life...

In recent paper [8], we have taken advantage of Pellet [11] reasoning services [14] to check its correctness. In the paper [8], a simple reasoning method is also developed for some WH-question such as what, where, when, who to OVL ontology. At that time, Pellet reasoned is also used to execute SPARQL query and ensure OVL was consistency. After applying reasoning strategies on OVL, our systems are now supporting more complex types of question such as why, how.

In this paper, we focus on using a Vietnamese Question Answering (QA) system to evaluate the OVL. In such systems, reasoning mechanisms based on the typical structure of OVL are well implemented to find answer for common type of questions.

\section{BUILDING A VIETNAMESE QUESTION ANSWERING SYSTEM TO VALUATE OVL}

After checking the correctness of the OVL using Pellet reasoning services, a QA system is implemented in order to estimate the OVL's answer competence.

Some related works are introduced in [1], [2], [3], [4], [5],

Manuscript received July 24, 2010; revised February 7, 2011.

Dang Tuan Nguyen, Tri Phi-Minh Nguyen, Faculty of Computer Science University of Information Technology Vietnam National University - Ho Chi Minh City(email: dangnt@uit.edu.vn, trinpm@gmail.com).
[6]. In these publications, a Vietnamese ontology in e-books library domain has been exploited to develop a searching tool based on QA model. This searching tool is built by using some natural language processing techniques. In this paper, we do not use the syntactic and semantic processing techniques like the techniques mentioned above.

The QA system to evaluate OVL executed as follows:

1) Determining keywords from user's query. This step is supported by pre-defined templates and a Vietnamese WordNet (WNVL: WordNet for Vietnamese Language) [9].

2) Generating SPARQL query from above keywords.

In general, there are two groups of questions are performed by our system:

Group 1: This group consists of question types such as who, what, where, when. In this group, the users can simply retrieve related information from OVL.

Group 2: This contains more complex types of question which require reasoning mechanisms from ontology such as why, how questions.

The method to answer questions in Group 1 (who, what, where, when) is basically based on determining keywords from Vietnamese questions. Finally, these keywords are passed to SPARQL query to retrieve triples from ontology. In OVL, a triple includes three items: subject, predicate, object. Therefore, to answer a question in the first group, it is necessary to find the most suitable item when receiving two remaining items in advance.

These specific steps to answer what, where, when, who questions are described in the following steps [8]:

Step 1: This is aimed at determining type of received question from user. Clarifying in question types basically depends on the appearance of some query words which are distinct for each type of question.

Step 2: Getting rid of meaningless words, extracting keyword which plays a role as a subject in a triple from query question.

Step 3: This is to extract keywords that are noticed as predicate item (representing for relationship between subject and object in triple). Subjects from previous step will be removed, the remaining items are considered as predicate. It is necessary to develop a procedure to list predicates which are in OVL matching with predicate from inputting question (in OVL, predicate is also called as object property or datatype property). This step follows:

Step 3.1: From OVL data, collecting predicates which match with the predicate from query. These predicates will be stored in set matchedPredicates $=\{\}$.

Step 3.2: Sorting elements in matchedPredicates with descending order in string's length. 
Step 4: SPARQL's query will be initialized with keyword from Step 2. The result of this query is a set of triples $\mathrm{T}$ (including subject, predicate, object) in which subject contains keyword from Step 2.

Step 5: This step is to traverse matchedPredicates set. A subject from Step 2 and each of appropriate elements in matchedPredicates form a pair. This pair is compared with each pair (subject, predicate) in T to retrieve corresponding objects. If the result is absolutely compared (two strings are totally similar), it is stored in highPriorityAns $=\{\}$. On the other hand, if the result is relatively compared (two strings are nearly similar), it is stored in lowPriorityAns $=\{\}$. Objects from highPriorityAns set are usually the exact answers to inputting question, and the answers from lowPriorityAns set are usually marked as responds for reference.

In Group 2, spine technique to find answers is based on reasoning on the default components of Ontology Web Language (OWL) [12]. The result of this reasoning will be the $r$ relationship between two individuals in OVL. Obviously, this $r$ relationship has not yet defined in the OVL.

In general, there are three main reasoning mechanisms to inspect the $r$ relationship to give answers for second group question (why, how). Whether, it is based on the characteristics of property in OWL (functional property or FP; inverse functional property or IFP; transitive property, TP; and symmetric property, SP) as shown in Figure 1; or relied on the domain and range of property; or finally, based on the definition of a class in ontology.

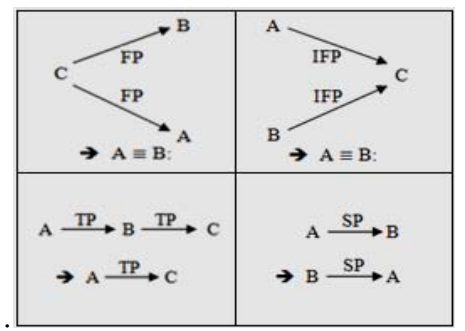

Figure 1: Characteristics of property and their functionality in OWL language [12].

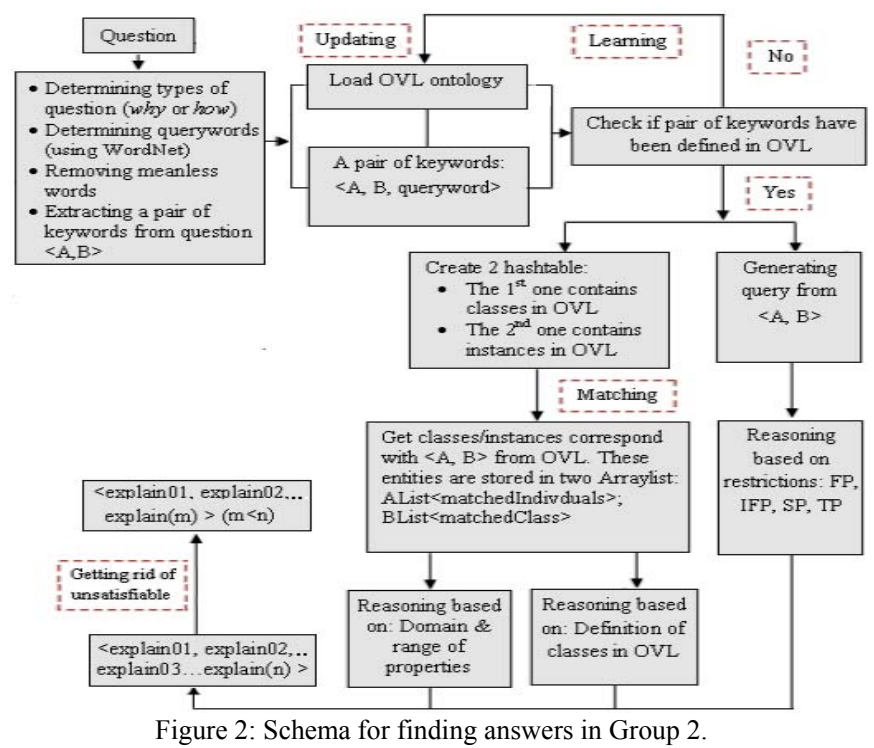

Schema, as illustrated in Figure 2, has been used to find answers with a why or how question on OVL. There are four main steps in such a scheme:
Step 1: To determine what type of question from user's question $q$. The system will remove meaningless words and find query word from question $q$. These procedures will be supported from WNVL's data synsets (WNVL [9]). At the end of this step, the inputting question from user is separated into three main items: kword_a, kword_b, queryword_c. From defined question templates and queryword_c, the system will notice whether the inputting question can be answered or not.

Step 2: To check whether a pair of $\left\langle k w o r d \_a, k w o r d \_b>\right.$ exists in ontology OVL or not. If not, the learning mechanism allows user to add data such as defining entities, classes, related relationships from question $q$ into the ontology. This method will enhance the answer competence of system in time. The necessary condition to continue next steps is that the pair $<k w o r d s \_a$, kwords_b $>$ must be defined in OVL. If this condition is satisfied, the auto-generated SPARQL will be constructed including the above $<k w o r d s \_a$, kwords_b $>$. The result from this query is stored in data table $t$.

Step 3: In this step, reasoning strategies are applied. This technique is based on default components of OWL language standard to find answer from question query $q$. The QA systems will traverse all of strategies until they find appropriate answers. Mechanisms of the reasoning include:

1) Reasoning mechanism relied on characteristics of property: based on the above data table, the system applies traits of property between individuals to seek for suitable answer. The next two strategies aim at inspecting "is-a" relationship between an individual and particular class in OVL. They will operate as following: verifying classes, individuals in OVL which are corresponding to kword_a and kword_b (matching technique).

2) Reasoning mechanism based on the domain and range of properties: searching properties in OVL which relate to class name extracted from $q$, and putting them into the set matchedProp $=\{\}$; and inspecting the set matchedProp in order to generate SPARQL query which includes individual name from query question $q$ and element in set matchedProp. The answer will be given by the system if the question returns the number of positive row.

3) Reasoning mechanism referred to the definition of a class: a SPARQL query will be formed by combining properties from the definition of a class with individuals extracted from query question $q$ respectively. If the result from query matches with definition of class, individuals and classes which are extracted from question $q$ will be noticed as existing "is-a" relationship. In this case, the explanation of the result is recorded from the above SPARQL query.

Step 4: This is to remove unsatisfiable answers to sort the most suitable ones. This step checks the ratio of the similarity between pairs of keywords from question and answers. For each of reasoning strategy, the system will have its own different mechanism to check each of the ratios of the similarity. For example, in case of reasoning based on functional property: The object from the first triple and the object from the second one have to contain kword_a or kword_b. 


\section{DEVELOPMENTS}

TABLE 1. EXPERIMENT RESULTS FOR QUESTIONS IN FIRST GROUP.

\begin{tabular}{|c|c|c|c|c|c|}
\hline Form & Question & HPA & LPA & Sum & $\begin{array}{l}\text { Time } \\
(\mathrm{ms})\end{array}$ \\
\hline \multirow{8}{*}{ What } & $\begin{array}{l}\text { Tỉnh Nghệ An có website } \\
\text { chính thức là gì? } \\
\text { (What is official website } \\
\text { of Nghe An province?) }\end{array}$ & 1 & 43 & 44 & 1666 \\
\hline & $\begin{array}{l}\text { Nghệ An có biển số xe } \\
\text { các loại là gì? } \\
\text { (What are car's } \\
\text { registration numbers in } \\
\text { Nghe An province?) }\end{array}$ & 4 & 21 & 25 & 3884 \\
\hline & $\begin{array}{l}\text { Thành phố Buôn Ma } \\
\text { Thuột có quy mô dân số } \\
\text { nội đô là bao nhiêu? } \\
\text { (What is population scale } \\
\text { in Buon Ma Thuoc city?) }\end{array}$ & 1 & 5 & 6 & 1219 \\
\hline & $\begin{array}{l}\text { Đà Nẵng có mã điện thoại } \\
\text { là gì? } \\
\text { (What is telephone code } \\
\text { in Da Nang city?) }\end{array}$ & 1 & 33 & 34 & 3030 \\
\hline & $\begin{array}{l}\text { Thủ đô Hà Nội có mã bưu } \\
\text { chính là gì? } \\
\text { (What is Ha Noi's postal } \\
\text { code?) }\end{array}$ & 4 & 104 & 108 & 1654 \\
\hline & $\begin{array}{l}\text { Huế có tỉ lệ lao động phi } \\
\text { nông nghiệp là bao } \\
\text { nhiêu? } \\
\text { (What is labour ration in } \\
\text { Hue province?) }\end{array}$ & 1 & 35 & 36 & 1329 \\
\hline & $\begin{array}{l}\text { Thành phố Đồng Hới } \\
\text { Thuộc Việt Nam là thành } \\
\text { phố nào? } \\
\text { (What is Dong Hoi in } \\
\text { Vietnam province?) }\end{array}$ & 0 & 2 & 2 & 9675 \\
\hline & $\begin{array}{l}\text { Thành phố Huế có mật độ } \\
\text { dân số là bao nhiêu? } \\
\text { (What is population } \\
\text { density in Hue city?) }\end{array}$ & 4 & 16 & 20 & 2802 \\
\hline \multirow[t]{4}{*}{ Where } & $\begin{array}{l}\text { Mã điện thoại } 710 \text { ở đâu? } \\
\text { (Where is telephone code } \\
710 ? \text { ) }\end{array}$ & 0 & 1 & 1 & 2446 \\
\hline & $\begin{array}{l}\text { Quận Tân Bình ở đâu? } \\
\text { (Where is Tan Binh } \\
\text { district?) }\end{array}$ & 0 & 1 & 1 & 2329 \\
\hline & $\begin{array}{l}\text { Mã bưu chính } 59 \text { ở đâu? } \\
\text { (Where is postal code } \\
59 \text { ?) }\end{array}$ & 0 & 1 & 1 & 1876 \\
\hline & $\begin{array}{l}\text { Biển số } 99 \text { ở đâu? } \\
\text { (Where is car registration } \\
\text { number 99?) }\end{array}$ & 0 & 1 & 1 & 1550 \\
\hline \multirow[t]{4}{*}{ When } & $\begin{array}{l}\text { Việt Nam gia nhập WTO } \\
\text { năm nào? } \\
\text { (When did Vietnam join } \\
\text { WTO?) }\end{array}$ & 1 & 62 & 63 & 1852 \\
\hline & $\begin{array}{l}\text { Hà Nội giải phóng năm } \\
\text { nào? } \\
\text { (When was Hanoi } \\
\text { emancipated?) }\end{array}$ & 1 & 59 & 60 & 6240 \\
\hline & $\begin{array}{l}\text { Chủ tịch Hò̀ Chí Minh } \\
\text { sinh năm nào? } \\
\text { (When was Ho Chi Minh } \\
\text { predident born?) }\end{array}$ & 0 & 1 & 1 & 1869 \\
\hline & $\begin{array}{l}\text { Ngân hàng Đông Á có } \\
\text { ngày thành lập là? } \\
\text { (When was Dong A bank } \\
\text { established?) }\end{array}$ & 1 & 5 & 6 & 1639 \\
\hline \multirow[t]{2}{*}{ Who } & $\begin{array}{l}\text { Cao Đức Phát là người } \\
\text { nào? } \\
\text { (Who is Cao Duc Phat?) }\end{array}$ & 0 & 2 & 2 & 9058 \\
\hline & $\begin{array}{l}\text { Ca khúc "Một cõi đi về" } \\
\text { được sáng tác bởi ai? } \\
\text { (Who is "Một cõi đi về" } \\
\text { song composed by?) }\end{array}$ & 1 & 0 & 1 & 9972 \\
\hline
\end{tabular}

In our QA systems, a list of about 200 questions which are formed from 28 pre-defined templates has been tested. The content of these questions basically relates to the defined knowledge in OVL and inputs randomly to systems. Processing procedures such as detecting types of question, extracting words and key words, etc. will be logged along with the final result.

Some tested questions in first group's question have listed in Table 1, its columns are described as following:

1) Form: Types of questions,

2) Question: Vietnamese questions,

3) High Priority Answer (HPA): Sum of the most suitable answers for input question,

4) Low Priority Answer (LPA): Sum of related answers for input question, which is used as references to question,

5) Sum: total retrieved answers from a question,

6) Time: time to get all answers from inputting question, in milliseconds.

The procedure to detect whether an answer will be classified into HPA set or LPA set is done automatically by systems through checking the similarity between the question and answers. The most appropriate answers corresponding to question are often stored in High Priority Answer set. In case that the system does not find out any answer in this set, the reason is that the predicate item from question does not match to any predicate from OVL's triples, so the user must track to find out the answer from LPA set. For example, with the question "Quận Tân Bình ở đâu?", there is no predicate such as " o" "or " $o ̛$ đâu" in OVL ontology, but predicates such as "thuộc" and "trục thuộc" accompany with keyword "Quận Tân Binh". Therefore sum of answers in HPA is 0 while LPA's is 2 (Table 2). In this situation, although answers in LPA have lower priority but they are still acceptable for this inputting question.

Table 2 includes templates for questions in second group along with their corresponding reasoning mechanism.

Items such as $<A>,<B>$ in templates are entities which are input from user. According to our observations from experimental results, the anwers from systems will be the most appropriate if the similarity between item $<A>$, item $<\mathrm{B}>$ and individuals in OVL are highest.

With questions in the second group's templates, our systems will traverse all implemented reasoning strategies until it can return suitable answers. In some cases, if the systems cannot solve the answer because of missing entities's definition, its learning mechanism will advocate to add data and its description to OVL.

TABLE 2. SECOND GROUP'S QUESTION TEMPLATES FOR VIETNAMESE QA SYSTEMS

\begin{tabular}{|l|l|l|l|}
\hline No. & Template & $\begin{array}{l}\text { Reasoning } \\
\text { mechanism }\end{array}$ & $\begin{array}{l}\text { Number } \\
\text { of tested } \\
\text { question } \\
\mathrm{S}\end{array}$ \\
\hline 00 & $\begin{array}{l}\text { <Tại sao> ngân hàng A và ngân } \\
\text { hàng B có phương thức hoạt động } \\
\text { tương tự nhau? } \\
\text { (Why do bank A and bank B have } \\
\text { the system similar to each } \\
\text { other?) }\end{array}$ & $\begin{array}{l}\text { Characteristic } \\
\text { of property } \\
\text { (Functional } \\
\text { Property) }\end{array}$ & 9 \\
\hline
\end{tabular}




\begin{tabular}{|c|c|c|c|}
\hline $\begin{array}{l}00 \\
2\end{array}$ & $\begin{array}{l}<\text { Tại sao }>\text { nhân vật/người } \mathrm{A} \text { và } \\
\text { nhân vật/người } \mathrm{B} \text { là cùng một } \\
\text { người? } \\
\text { (Why do person } A \text { and person } B \\
\text { indicate the same person?) }\end{array}$ & $\begin{array}{l}\text { Characteristic } \\
\text { of property } \\
\text { (Functional } \\
\text { Property) }\end{array}$ & 9 \\
\hline $\begin{array}{l}00 \\
3\end{array}$ & $\begin{array}{l}<\text { Tại sao }>\text { địa danh } \mathrm{A} \text { và địa danh } \\
\mathrm{B} \text { là cùng một nơ ơ Việt Nam? } \\
\text { (Why do place } A \text { and place } B \\
\text { indicate the same place in } \\
\text { Vietnam?) }\end{array}$ & $\begin{array}{l}\text { Characteristic } \\
\text { of property } \\
\text { (Inverse } \\
\text { Functional } \\
\text { Property) }\end{array}$ & 7 \\
\hline $\begin{array}{l}00 \\
4\end{array}$ & $\begin{array}{l}<\text { Tại sao }>\text { công ty } \mathrm{A} \text { và công ty } \mathrm{B} \\
\text { có chung ngành hàng kinh } \\
\text { doanh? } \\
\text { (Why do company } A \text { and } \\
\text { company B have the same } \\
\text { enterprise?) }\end{array}$ & $\begin{array}{l}\text { Characteristic } \\
\text { of property } \\
\text { (Inverse } \\
\text { Functional } \\
\text { Property) }\end{array}$ & 13 \\
\hline $\begin{array}{l}00 \\
5\end{array}$ & $\begin{array}{l}<\text { Tại sao }>\text { doanh nghiệp } \mathrm{A} \text { và } \\
\text { doanh nghiệp } \mathrm{B} \text { có nguồn lực tài } \\
\text { chính tương đương nhau? } \\
\text { Why do company } A \text { and company } \\
B \text { have the financial competence } \\
\text { equivalently? }\end{array}$ & $\begin{array}{l}\text { Characteristic } \\
\text { of property } \\
\text { (Inverse } \\
\text { Functional } \\
\text { Property) }\end{array}$ & 9 \\
\hline $\begin{array}{l}00 \\
6\end{array}$ & $\begin{array}{l}<\text { Tại sao }>\text { cơ quan } \mathrm{A} \text { và cơ quan } \\
\mathrm{B} \text { là hai cơ quan ngang cấp } \\
\text { nhau? } \\
\text { (Why is agency A equivalent to } \\
\text { agency B?) }\end{array}$ & $\begin{array}{l}\text { Characteristic } \\
\text { of property } \\
\text { (Inverse } \\
\text { Functional } \\
\text { Property) }\end{array}$ & 8 \\
\hline $\begin{array}{l}00 \\
7\end{array}$ & $\begin{array}{l}<\text { Tại sao }>\text { môn thể thao } \mathrm{A} \text { và môn } \\
\text { thể thao } \mathrm{B} \text { có phương pháp tính } \\
\text { diểm tương tự nhau? } \\
\text { (Why do sport subject } A \text { and } \\
\text { sport subject B have the same } \\
\text { score methodology?) }\end{array}$ & $\begin{array}{l}\text { Characteristic } \\
\text { of property } \\
\text { (Inverse } \\
\text { Functional } \\
\text { Property) }\end{array}$ & 8 \\
\hline $\begin{array}{l}00 \\
8\end{array}$ & $\begin{array}{l}<\text { Tại sao }>\text { đơn vị/ cơ quan } \mathrm{A} \\
\text { thuộc quản lý của đơn vị/ cơ quan } \\
\mathrm{B} \text { ? } \\
\text { (Why does agency A belong to } \\
\text { agency B?) }\end{array}$ & $\begin{array}{l}\text { Characteristic } \\
\text { of property } \\
\text { (Transitive } \\
\text { Property) }\end{array}$ & 7 \\
\hline $\begin{array}{l}00 \\
9\end{array}$ & $\begin{array}{l}<\text { Tại sao> thiết bị } \mathrm{A} \text { là thành } \\
\text { viên/bộ phận của lớp } \mathrm{B} \text { ? } \\
\text { (Why does instance A belong to } \\
\text { class B?) }\end{array}$ & $\begin{array}{l}\text { Domain and } \\
\text { Range of } \\
\text { Property }\end{array}$ & 7 \\
\hline $\begin{array}{l}01 \\
0\end{array}$ & $\begin{array}{l}\text { <Tại sao> khách sạn A được xếp } \\
\text { vào khách sạn n sao tại Việt } \\
\text { Nam? } \\
\text { (Why is hotel A classified into } n \\
\text { star hotel in Vietnam?) }\end{array}$ & $\begin{array}{l}\text { Class } \\
\text { Definition }\end{array}$ & 10 \\
\hline $\begin{array}{l}01 \\
1\end{array}$ & $\begin{array}{l}\text { Chất lượng dịch vụ của công ty } \mathrm{A} \\
\text { <như thế nào>? } \\
\text { (How is the service quality of } \\
\text { company A?) }\end{array}$ & $\begin{array}{l}\text { Class } \\
\text { Definition }\end{array}$ & 10 \\
\hline $\begin{array}{l}01 \\
2\end{array}$ & $\begin{array}{l}\text { A và } \mathrm{B} \text { có quan hệ như thế nào } \\
\text { với nhau tai việt nam? } \\
\text { (How is the relationship between } \\
\text { object } A \text { and object } B \text { in } \\
\text { Vietnam?) }\end{array}$ & $\begin{array}{l}\text { Characteristic } \\
\text { of property } \\
\text { (Transitive } \\
\text { Property) }\end{array}$ & 7 \\
\hline $\begin{array}{l}01 \\
3\end{array}$ & $\begin{array}{l}\text { Quan hệ giữa cá thể } \mathrm{A} \text { và lớp } \mathrm{B} \text { là } \\
\text { <như thề nào>? } \\
\text { (How is the membership between } \\
\text { instance } A \text { and class } B \text { ?) }\end{array}$ & $\begin{array}{l}\text { Class } \\
\text { Definition } \\
\text { (Class } \\
\text { Definition) }\end{array}$ & 7 \\
\hline
\end{tabular}

\section{CONCLUSIONS}

The OVL has been evaluated using its effects as real component in question answering systems. This evaluation method helps us estimate the competence of OVL through following answered questions: which reasoning mechanism can be built up on OVL's structure and knowledge domain, which types of question can be answered from these reasoning mechanism, how to evaluate the experimental results.

TABLE 3. SOME EXPERIMENTED QUESTIONS FROM SECOND GROUP'S QUESTIONS

\begin{tabular}{|c|c|c|c|}
\hline No. & Template & $\begin{array}{l}\text { Reasoning } \\
\text { mechanism }\end{array}$ & $\begin{array}{l}\text { Evaluated } \\
\text { answers } \\
\text { (by user) }\end{array}$ \\
\hline $\begin{array}{l}00 \\
1\end{array}$ & $\begin{array}{l}\text { Tại sao ngân hàng ANZ Việt } \\
\text { Nam và ngân hàng HSBC có } \\
\text { phương thức hoạt động tương tự } \\
\text { nhau? } \\
\text { (Why do ANZ bank and HSBC } \\
\text { bank have the system similar to } \\
\text { each other?) }\end{array}$ & FP & $\checkmark$ \\
\hline $\begin{array}{l}00 \\
2\end{array}$ & $\begin{array}{l}\text { Tại sao Nguyễn Ái Quốc và Hồ } \\
\text { Chí Minh là cùng một người? } \\
\text { (Why do Nguyen Ai Quoc and Ho } \\
\text { Chi Minh indicate the same } \\
\text { person?) }\end{array}$ & FP & $\checkmark$ \\
\hline $\begin{array}{l}00 \\
3\end{array}$ & $\begin{array}{l}\text { Tại sao Bến Nghé và Gia Định là } \\
\text { cùng một địa danh ở việt nam? } \\
\text { (Why do Ben Nghe and Gia Dinh } \\
\text { indicate the same place in } \\
\text { Vietnam?) }\end{array}$ & IFP & $\checkmark$ \\
\hline $\begin{array}{l}00 \\
4\end{array}$ & $\begin{array}{l}\text { Tại sao công ty AIGI và công ty } \\
\text { Duy Tân có chung ngành hàng } \\
\text { kinh doanh? } \\
\text { (Why do company } A \text { and } \\
\text { company } B \text { have the same } \\
\text { enterprise?) }\end{array}$ & FP/IFP/TP/SP & \\
\hline $\begin{array}{l}00 \\
5\end{array}$ & $\begin{array}{l}\text { Tại sao doanh nghiệp Việt Nhật } \\
\text { và tập đoàn FPTW có nguồn lực } \\
\text { tài chính tương đương nhau? } \\
\text { (Why do company A and } \\
\text { company B have the financial } \\
\text { competence equivalently?) }\end{array}$ & FP/IFP/TP/SP & \\
\hline $\begin{array}{l}00 \\
6\end{array}$ & $\begin{array}{l}\text { Tại sao Khách sạn Caravelle } \\
\text { được xếp vào khách sạn } 5 \text { sao tại } \\
\text { Việt Nam?) } \\
\text { (Why is Caravelle hotel } \\
\text { classified into five star hotel in } \\
\text { Vietnam?) }\end{array}$ & $\begin{array}{l}\text { Domain and } \\
\text { Range of } \\
\text { Property }\end{array}$ & $\checkmark$ \\
\hline $\begin{array}{l}00 \\
7\end{array}$ & $\begin{array}{l}\text { Tại sao bộ môn Bóng Bàn và bộ } \\
\text { môn Cầu Lông có phương pháp } \\
\text { tính điểm tương tự nhau? } \\
\text { (Why do sport subject } A \text { and sport } \\
\text { subject B have the same score } \\
\text { methodology?) }\end{array}$ & IFP & $\checkmark$ \\
\hline $\begin{array}{l}00 \\
8\end{array}$ & $\begin{array}{l}\text { Chất lượng dịch vụ của công ty } \\
\text { Vietravel như thế nào? } \\
\text { (How is the service quality of } \\
\text { Vietravel?) }\end{array}$ & $\begin{array}{l}\text { Class } \\
\text { definition }\end{array}$ & $\checkmark$ \\
\hline $\begin{array}{l}00 \\
9\end{array}$ & $\begin{array}{l}\text { Tại sao công ty PVEP Algeria } \\
\text { trực thuộc Tập Đoàn Dầu Khí } \\
\text { Quốc Gia? } \\
\text { (Why does PVEP Algeria agency } \\
\text { belong to Petro Vietnam Corp.?) }\end{array}$ & $\mathrm{TP}$ & $\checkmark$ \\
\hline $\begin{array}{l}01 \\
0\end{array}$ & $\begin{array}{l}\text { Quan hệ giữa cá thể Vỏ } 2759 \text { và à } \\
\text { lớp Phụ Tùng Xe Máy là như thế } \\
\text { nào? } \\
\text { (How is the relationship between } \\
\text { tire } 2759 \text { and class motobike } \\
\text { equipment?) }\end{array}$ & $\begin{array}{l}\text { Domain and } \\
\text { Range of } \\
\text { Property }\end{array}$ & \\
\hline
\end{tabular}

Two different techniques to answer two groups of questions are described in details. They both take advantage of Vietnamese Wordnet (WNVL [9]) and defined templates to detecting types of question, extracting key words and useful query words from user. The first group of questions mainly queries information from OVL, while with the second group, some different reasoning strategies are applied to find 
the answers. The OVL's tester will input question based on templates and keep track of return answers. Besides, the procedure to check the correctness of OVL through Pellet reasoned is mandatory before using QA systems and exploiting OVL's application in the future.

According to our experiments: questions in Group 1 (what, who, where, when) will be solved if the user provided two out of three items of corresponding triples; question in Group 2 (why, how) required related entities have to defined in details along with restrictions, relationships.

The next important task is to apply Vietnamese grammar analyzing methods and semantic processing techniques along with increase data for OVL up to many times, to enhance more complex Vietnamese QA systems which can support complicated types of queries such as sub-query, negative query, etc. At that time, our QA system will evaluate and exploit the OVL ontology easily and more efficiently.

\section{REFERENCES}

[1] Dang Tuan Nguyen, Ha Quy-Tinh Luong, "A framework for building Vietnamese language query processing components in e-library searching systems", International Conference on Information Technology (ICIT 2009), Venice, Italy, October 28-30, 2009. Proceedings of World Academy of Science, Engineering and Technology, pp. 1354-1358, Vol. 58, October 2009. ISBN: 2070-3724.

[2] Dang Tuan Nguyen, Ha Quy-Tinh Luong, Tuyen Thi-Thanh Do, "Building a Vietnamese language query processing framework for e-library searching systems", International Journal of Computer Science and Information Security (IJCSIS), pp. 092-096, Vol. 6, No. 1, October 2009. ISSN: 1947-5500.

[3] Dang Tuan Nguyen, Ha Quy-Tinh Luong, "Document searching system based on natural language query processing for Vietnam Open Courseware library", International Journal of Computer Science Issues (IJCSI), pp. 7-13, Vol. 6, No. 2, November 2009. ISSN (online): 1694-0784, ISSN (print): 1694-0814.

[4] Dang Tuan Nguyen, Tuan Ngoc Pham, Quoc Tan Phan, "A Semantic Model for Building the Vietnamese Language Query Processing Framework in e-Library Searching Application", Proceedings of the 2nd International Conference on Machine Learning and Computing (ICMLC 2010), pp. 179-183, February 9-11, 2010, Bangalore, India. ISBN: 978-0-7695-3977-5. Editions IEEE.
[5] Dang Tuan Nguyen, Huy Vu Nguyen, Quoc Tan Phan, "Using the Vietnamese Language Query Processing Framework to Build a Courseware Searching System", The 2010 International Conference on Telecom Technology and Applications (ICTTA 2010), Proceedings of the 2010 Second International Conference on Computer Engineering and Applications, Vol. 2, pp. 117-121, March 19 - 21, 2010, Bali Island, Indonesia. ISBN: 978-0-7695-3982-9. Editions IEEE.

[6] Dang Tuan Nguyen, Ha Quy-Tinh Luong, Quoc Tan Phan, "An e-Library Searching System Based on the Vietnamese Language Query Processing Framework", The 2010 International Conference on Information and Emerging Technologies (ICIET 2010), Proceedings of the 2010 Second International Conference on Computer Engineering and Applications, Vol. 2, pp.517-520, Bali Island, Indonesia, March 19 - 21, 2010. ISBN: 978-0-7695-3982-9. Editions IEEE.

[7] Dang Tuan Nguyen, Tri Phi-Minh Nguyen, "Building and Evaluation of a Universal Ontology for Vietnamese Language", Proceedings of the 3rd International Conference on Advanced Computer Theory and Engineering 2010 (ICACTE 2010), Vol. 6, pp. 227-230, August 20-22, 2010, Chengdu, China. Editions IEEE.

[8] Dang Tuan Nguyen, Tri Phi-Minh Nguyen, "Pellet Reasoner Based Evaluation of OVL (Ontology for Vietnamese Language)", Proceedings of the 2010 2nd International Conference on Software Technology and Engineering (ICSTE 2010), Vol. 2, pp. 180-184, October 3-5, 2010, San Juan, Puerto Rico, USA. Editions IEEE.

[9] Dang Tuan Nguyen, Tu Ngoc Nguyen, "Building a WordNet for Vietnamese Language", Proceedings of the 2010 International Conference on Intelligence and Information Technology (ICIIT 2010), Vol. 1, pp. 605-609, October 28-30, 2010, Lahore, Pakistan. Editions IEEE.

[10] Nguyen Phi Minh Tri, Nguyen Ngoc Tu, "Xây dựng công cụ truy vấn thông tin hướng tri thức-ngữ nghĩa trên ontology tiếng Việt”, B.Sc. Thesis in Computer Science, University of Information Technology, Vietnam National University - Ho Chi Minh City, 2010.

[11] Evren Sirin, Bijan Parsia, Bernardo Cuenca Grau, Aditya Kalyanpur, Yarden Katz, "Pellet: A practical OWL-DL reasoner", Web Semantics: Science, Services and Agents on the World Wide Web, v.5 n.2, p.51-53, June, 2007.

[12] http://www.w3.org/TR/owl-features/

[13] http://ovl-open.sourceforge.net

[14] http://clarkparsia.com/pellet 